\title{
PERANAN PEMIKIRAN POLITIK HATTA TERHADAP KOPERASI GADING ARTHA BATAM TAHUN 2015-2017
}

\section{THE ROLE OF HATTA POLITICAL THINKING ARTHA BATAM COOPERATIVES ON 2015-2017}

\author{
Laura Nopriza ${ }^{1}$, Desma $_{\text {Yulia }}{ }^{2}$ \\ Program Studi Pendidikan Sejarah, Fakultas Keguruan dan Ilmu Pendidikan \\ Universitas Riau Kepulauan, Indonesia \\ Lauranopriza@yahoo.co.id, Desmayulia48@gmail.com
}

\begin{abstract}
Abstrak
Peranan pemikiran Hatta terhadap Koperasi Gading Artha Batam yaitu dengan adanya pemikiran Hatta ini mengenai koperasi, mempengaruhi sebuah koperasi yang ada di Batam. salah satunya Koperasi Gading Artha. Koperasi ini terbentuk pada tahun 2015. Koperasi ini sangat membantu masyarakat ketika membutuhkan bantuan mendesak. koperasi ini memberi pengaruh terhadap kehidupan ekonomi masyarakat di kota Batam. Terbentuknya sebuah lembaga koperasi, salah satunya koperasi Gading Artha Batam merupakan peranan dari pemikiran politik Hatta. Berdirinya koperasi ini dipengaruhi oleh pemikiran politik Hatta. Ide pendiri koperasi Gading Artha batam dalam membangun sebuah koperasi dilatarbelakangi oleh pemikiran politik Hatta, sehingga pemikiran politik Hatta sangat berperan penting sekali dalam pendirian sebuah koperasi yaitu koperasi Gading Artha Batam.Kemudian dengan adanya koperasi Gading Artha dapat mempengaruhi kehidupan sosial rakyat Indonesia yaitu menumbuhkan rasa solidaritas dan meningkatkan rasa tanggung jawab dalam setiap pribadi. Sehingga peranan pemikiran Hatta sangat berperan sekali untuk awal berdirinya sebuah Koperasi yaitu Koperasi Gading Artha yang berpengaruh terhadap kehidupan sosial ekonomi masyarakat.
\end{abstract}

Kata Kunci : Peranan, Pemikiran, Hatta

\begin{abstract}
The role of Hatta's thoughts on the Gading Artha Batam Cooperative, namely the presence of Hatta's thoughts on cooperatives, influenced a cooperative in Batam. one of them is Gading Artha Cooperative. This cooperative was formed in 2015. The cooperative is very helpful to the community when it needs urgent assistance. This cooperative influences the economic life of the people in Batam city. The establishment of a cooperative institution, one of which is the Gading Artha Batam cooperative, is a role for Hatta's political thinking. The establishment of the cooperative was influenced by Hatta's political thinking. The idea of the founder of the Gading Artha batam cooperative in building a cooperative was motivated by Hatta's political thinking, so Hatta's political thinking was very important in establishing a cooperative namely the Gading Artha Batam cooperative. Then with the Gading Artha cooperative it could influence the social life of the Indonesian people which fostered a sense of solidarity and increase the sense of responsibility in each person. So that the role of Hatta's thought was very instrumental for the establishment of a Cooperative namely the Gading Artha Cooperative which had an influence on the socio-economic life of the community.
\end{abstract}

Keywork: Role, thought, Hatta 


\section{PENDAHULUAN}

Perkembangan sejarah Indonesia tidak bisa dilepaskan dari peran para pencetus atau pahlawan bangsa. Salah satunya Hatta. Penelitian tentang Hatta sebagai seorang pahlawan bangsa telah banyak ditulis oleh sejarawan baik sejarah nasional maupun sejarah lokal. Akan tetapi belum ada penelitian yang menuliskan peranan pemikiran politik Hatta terhadap kehidupan sosial ekonomi rakyat Indonesia tahun 1945-1970.

Hatta sebagai wakil presiden Republik Indonesia pertama merupakan sosok yang berpengaruh terutama pada masa kemerdekaan Indonesia tahun 1945. Terwujudnya cita-cita bangsa Indonesia tentu tidak terlepas dari pemikiranpemikiran Hatta, Sehingga disebut sebagai salah satu the founding father Indonesia (Effendi, 2014: 5).

Hatta dikenal sebagai bapak Koperasi Indonesia. Salah satu jasanya yang cukup besar adalah sumbangan pemikirannya tentang pentingnya koperasi. Baik sebagai konsep ekonomi maupun untuk membangun golongan ekonomi lemah. Pemikiran-pemikirannya itulah yang kemudian dirumuskan dalam pasal 33 Undang-Undang Dasar 1945. Selain itu Hatta juga merupakan seorang tokoh politik yang sangat erat kaitannya dengan kehidupan rakyat Indonesia. Pemikiran-pemikiran politik Hatta tentu berpengaruh terhadap kehidupan sosial ekonomi rakyat Indonesia (Effendi, 2014: 87) . 


\section{METODE PENELITIAN}

Jenis penelitian yang digunakan pada penelitian ini adalah penelitian kualitatif historis yaitu penelitian yang bertujuan untuk merekonstruksi masa lampau secara sistematis dan objektif, dengan cara mengumpulkan, mengevaluasi, memverifikasi, serta mensintesiskan bukti-bukti untuk meningkatkan fakta dan memperoleh kesimpulan yang kuat (Suryabrata, 2014: 73).

Dalam penelitian ini penulis menggunakan metode sejarah. Menurut Gilbert J. Garragan, S.J. (dalam Daliman, 2012: 27) bukunya A Guide to Historical Method mendefinisikan metode sejarah sebagai seperangkat asas dan aturan yang sistematik yang didesain guna membantu secara efektif untuk mengumpulkan sumber-sumber sejarah, menilainya secara kritis, dan menyajikan sintesis hasil-hasil yang dicapainya, yang pada umumnya dalam bentuk tertulis.

\section{PEMBAHASAN}

Drs. Mohammad Hatta merupakan salah satu founding father Indonesia, yang lebih dikenal dengan sebutan Bung Hatta. Sebutan "Bung" pada bagian depan namanya kemungkinan diberikan sebagai pengindetikan Hatta sebagai tokoh “Dwi Tunggal” pemimpin Indonesia, yakni Bung Karno dan Bung Hatta. Hatta dilahirkan pada tanggal 12 Agustus 1902 di Bukit Tinggi, Sumatera Barat. Ia meninggal di Jakarta pada tanggal 14 Maret 1980 saat usianya menginjak 77 tahun. Jenazah Hatta kemudian dimakamkan di Tanah Kusir, Jakarta. Pada tanggal 19 Oktober 1986, melalui Keppres No. 1881/1986 yang dikeluarkan oleh Presiden Soeharto, Hatta ditetapkan sebagai Pahlawan Nasional. 


\section{A. Pemikiran Politik Hatta}

Hatta sebenarnya lebih dikenal sebagai bapak koperasi Indonesia. Dialah yang telah menjadi peletak dasar-dasar terbentuknya koperasi di Indonesia. Hatta sempat besitegang dengan Bung Karno, khususnya pada saat Bung Karno menerapkan sistem Demokrasi Terpimpin. Menurut Hatta, sistem demokrasi terpimpin merupakan sistem otoriter yang dapat membunuh nilai-nilai demokrasi itu sendiri.

\section{B. Hatta dan Political Praxis}

Yang dimaksudkan political praxis di sini lebih dari sekedar praktik politik yang disebut sebagai political activism, aktivisme politik, akan tetapi praktik politik, praxis sebagai konsekuensi renungan-renungan politik yang dikerjakan seseorang lexis, dan dalam hal ini lexis dan praxis milik dan khas Hatta. Renungan yang dimaksudkan di sini juga persis seperti apa yang sudah lama dikemukakan di Belanda, pada saat pergantian kepemimpinan Perhimpunan Indonesia, yaitu "dasar-dasar yang akan berperan sebagai petunjuk arah bagi masyarakat " political praxis yang diambil di sini sebagai sesuatu yang khas Hatta, dengan mengabaikan yang lain, dalam seluruh perjuangan politiknya adalah menolak Volksraad dengan konsekuensi logisnya suatu gerakan nonkoperatif.

\section{Pemikiran Hatta Tentang Politik Luar Negeri}

Pada tanggal 2 September 1948, Hatta mengumumkan dalam politik luar negeri Indonesia dihadapan komite nasional Indonesia pusat (KNIP). Selain itu, Hatta juga menyatakan ide politik luar negeri tersebut melalui pidatonya yang 
berjudul mendayung di antara dua karang. Pidato inilah yang kemudian menjadi pijakan bagi Mochtar Kusumaatmaja yang menganggap Hatta sebagai peletak politik luar negeri pertama di Indonesia.

\section{Demokrasi Barat Dalam Pandangan Hatta}

Hatta pengeritik utama demokrasi barat, apabila diamati kritik-kritik Hatta terhadap demokrasi barat, yang dimaksudkannya bukanlah demokrasi Barat dalam arti politik, yaitu demokrasi dalam kehidupan politik, melainkan liberalisme secara umum. Dalam brosur kearah Indonesia Merdeka, Hatta mengemukakan sebagai berikut :

“ jadinya, demokrasi Barat yang dilahirkan oleh Revolusi Perancis tiada membawa kemerdekaan rakyat yang sebenarnya, melainkan menimbulkan kekuasaan kapitalisme, sebab itu demokrasi politik saja tidak cukup untuk mencapai demokrasi yang sebenarnya, yaitu kedaulatan rakyat, haruslah ada pula demokrasi ekonomi.

\section{E. Pemikiran Hatta Tentang Kebangsaan}

Pandangan Hatta tentang kebangsaan merujuk pada pemikiran Ernest Renan. Selain itu, pemikiran Hatta juga terpengaruh oleh pemikiran Offo Bauer dan Lothrop Stoddard. Menurut Hatta, rasa nasionalisme atau kebangsaan timbul karena adanya perasaan senasib yang telah tertanam dalam diri bangsa Indonesia. terkait dengan hal ini, Hatta tegaskan bahwa nasionalisme itu ditentukan oleh adanya kesadaran akan persamaan dan tujuan. Lebih jauh lagi, Hatta memberikan penilaiannya tentang keragaman konsep nasionalisme yang terdapat di Indonesia. 
menurut Hatta, setidaknya terdapat tiga macam kebangsaan, yaitu kebangsaan cap ningrat, kebangsaan intelek, dan terakhir adalah kebangsaan cap rakyat.

\section{F. Hatta dan Pandangan Teoritis}

Menurut Hatta, Momen pergantian kepemimpinan perhimpunan Indonesia tidak sekedar menjadi upacara penyerahan tugas dan kewajiban organisasi, akan tetapi oleh Hatta dimanfaatkan sebagai medan berlangsungnya beberapa hal. Pertama, adalah hak teknis organisasi, yaitu pergantian kepemimpinan. Kedua, adalah peristiwa politik, yang menanamkan kesadaran bahwa organisasi yang dibentuk itu adalah organisasi politik, dan karena itu kesempatan tersebut tidak bisa dilewati begitu saja, akan tetapi harus dijemput sebagai peristiwa politik dalam arti yang lain, yaitu sebagai mimbar tuntutan politik kepada belanda di tanahnya sendiri, dan ibu kotanya sendiri bahwa ada masalah besar dalam pola hubungan antara Indonesia dan Belanda. Karena itu, Hatta langsung mengambilnya dijadikan "dasar-dasar yang akan berperan sebagai petunjuk arah bagi masyarakat”. Ketiga, Hatta memaknai sebuah kesempatan itu menjadi peristiwa akademis untuk memaparkan teori-teorinya yang bermanfaat bagi dua keperluan diatas, yaitu bagi organisasi dan tuntutan kepada pemerintah kolonial dirumahnya sendiri.

\section{G. Ekonomi Indonesia di Masa Datang}

Dalam pidato pada pembukaan konferensi ekonomi di Yogyakarta tahun 1946, Hatta mengucapkan “ Dalam saat yang sesingkat ini tentu tak dapat saya merancang susunan ekonomi Indonesia yang selengkapnya bagi masa datang. Hanya beberapa garis yang besar saya dapat dikemukakan disini. Dasar politik 
perekonomian republik Indonesia terpancang dalam Undang-Undang dasar kita, dalam bab "Kesejahteraan Sosial”, Pasal 33 yang begini bunyinya:

1. "Perekonomian disusun sebagai usaha bersama berdasar atas azaz kekeluargaan.

2. Cabang produksi yang penting bagi negara dan yang menguasai hajat hidup orang banyak dikuasai oleh negara.

3. Bumi dan air dan kekayaan alam yang terkandung di dalamnya dikuasai oleh negara dan dipergunakan untuk sebesar-besarnya kemakmuran rakyat".

\section{H. Ekonomi Kerakyatan}

Ekonomi kerakyatan sebenarnya bukan merupakan ide baru, apalagi asing dalam konsep perekonomian nasional. Bahkan, ide ekonomi kerakyatan tersebut gemanya sudah mulai terasa pada masa awal-awal kemerdekaan. Perdebatan mengenai ekonomi kerakyatan dimulai ketika para pendiri republik ini merumuskan dasar negara dan Undang-Undang Dasar 1945.

Kerakyatan merupakan asas yang kedua dari pendidikan Nasional Indonesia. Hatta membicarakan kerakyatan dalam rangka membangun Indonesia merdeka. Hatta menambahkan, kerakyatan di sini berbeda dengan pengertian tentang kerakyatan yang umum dipakai yang biasanya berarti kerakyatan berdasarkan demokrasi barat.

Dalam Seminar koperasi di Yogyakarta tahun 1958 Hatta Mengatakan "Sudah lama bahwa sistem pengajaran yang kita pusakai dari masa penjajahan dahulu tidak sesuai dengan keperluan negara dan masyarakat untuk membangun. 
Untuk membangun kita memerlukan tenaga-tenaga yang berpengetahuan VAK (Visual, Auditor, Kinestetik) dalam segala tingkatan, tingkatan rendah, tingkatan menengah dan tingkatan tinggi. Kita tidak saja memerlukan tenaga insinyur, dokter, agronom, ekonom, juris yang berpendidikan sekolah tinggi, tetapi juga ahli menengah untuk menjadi pendorong dan pengawas beserta ahli-ahli VAK (Visual, Auditor, Kinestetik) rendah untuk memberi petunjuk langsung kepada kaum buruh yang melakukan pekerjaan.

\section{Gagasan dan Pemikiran Hatta pada hari-hari Koperasi Nasional}

Pidato Hatta pada hari koperasi 1 Tahun 1951: "Sebagai suatu bangsa yang berpuluh-puluh tahun berjuang menentang imperialisme dan kolonialisme, kita mempunyai idealisme, cita-cita tinggi, tentang dasar hidup kita. Kita ingin melihat bangsa kita hidup makmur dan sejahtera, bebas dari kesengsaraan hidup. Idealisme kita itu terpancang dalam Undang-Undang Dasar "Perekonomian disusun sebagai usaha bersama berdasar atas azaz kekeluargaan”. Azaz kekeluargaan itu ialah koperasi! Perkataan Undang-Undang dasar ini bukanlah hanya suatu pernyataan daripada idealisme bangsa kita, tetapi juga suruhan untuk bekerja ke jurusan itu.

\section{J. Sejarah Berdirinya Koperasi Gading Artha}

Berdirinya koperasi Gading Artha ini tidak terlepas dari peranan pemikiran Hatta mengenai sebuah koperasi. Koperasi Gading Artha berdiri sejak tahun 2015 hingga sekarang ini, ada beberapa program kerja Gading Artha antara lain meningkatkan mutu kinerja karyawan dan perusahaan, menambah relasi 
untuk memperluas jaringan, menambah usaha online barang import. Seperti dikatakan oleh bapak Dulaswan :

"Koperasi sebagai lembaga keuangan, jadi sebagai lembaga keuangan saya membuat koperasi ini di dalam masyarakat, orang dapat belajar berwirausaha melalui koperasi ini" (Wawancara pada tanggal 24 Agustus 2017).

Koperasi Gading Artha memiliki banyak manfaat bagi anggotanya terutama dengan adanya koperasi dapat memberi pelajaran dalam berbisnis, melatih diri untuk membuka usaha. Kemudian dalam sosial dapat meningkatkan rasa solidaritas antar sesama anggota koperasi dan juga menambah kerjasama untuk setiap anggota koperasi.

Modal yang didapatkan oleh koperasi Gading Artha yaitu berasal dari sumbangan dan iuran para anggota koperasi dalam menjalin kerja sama antar anggota untuk mengembangkan koperasi Gading Artha. Pendapatan koperasi Gading Artha di keluarkan untuk pinjaman sesama anggota dan tambahan lain seperti gadai barang yang sudah menjadi prioritas untuk pengembangan usaha yang baru, dan di dukung modalnya dari pendapatan pinjaman koperasi sesama anggota dalam memperluas jaringan usaha.

Koperasi Gading Artha memberi kesempatan untuk siapa saja yang ingin menjadi anggota dan berperan serta dalam berwirausaha, kemudian bekerja sama dalam koperasi untuk meningkatkan kesejahteraan dan derajat perekonomian umat yang sesuai dengan tujuan koperasi. Bagi hasil dari pendapatan sesama anggota ini dapat menuju sebuah kesejahteraan anggota koperasi. Hal ini seperti dipaparkan oleh bapak Kyi Shin, beliau mengatakan : 
"tujuan simpan pinjam di dalam hak kelompok, bagi hasil, gadai barang, simpan pinjam biasanya lebih banyak yang pinjam" (Wawancara pada tanggal 22 Agustus 2017).

Koperasi ini sangat membantu masyarakat ketika membutuhkan bantuan mendesak, tentu saja koperasi ini memberi pengaruh terhadap kehidupan ekonomi masyarakat di kota Batam. Kemudian dengan adanya koperasi Gading Artha dapat mempengaruhi kehidupan sosial rakyat Indonesia yaitu menumbuhkan rasa solidaritas dan meningkatkan rasa tanggung jawab dalam setiap pribadi. Sehingga peranan pemikiran Hatta sangat berperan sekali untuk awal berdirinya sebuah Koperasi yaitu Koperasi Gading Artha yang berpengaruh terhadap kehidupan sosial ekonomi masyarakat.

"koperasi ini kalau saya lihat perkembangannya sangat kaku terutama di Batam, jumlah anggota karyawan sekitar 53 anggota sekarang" (Wawancara pada tanggal 24 Agustus 2017).

Menurutnya sebuah koperasi berkembangnya sangat kaku sekali, tidak banyak masyarakat memilih untuk menggunakan koperasi, terutama di kota Batam. Banyak sekali koperasi yang tidak berhasil atau gagal. Penyebabnya karena masyarakat lebih memilih bank untuk menyimpan dan menabung uang.

\section{KESIMPULAN DAN SARAN}

\section{a. Kesimpulan}

Pemikiran Politik Hatta mempengaruhi Koperasi yang ada di kota Batam, koperasi tersebut bernama Koperasi Gading Artha, koperasi ini berjalan sejak tahun 2015 hingga saat ini. Banyak manfaat dari koperasi ini yaitu untuk mempermudah masyarakat dalam memenuhi kebutuhan 
hidup saat terdesak. Koperasi ini melatih untuk mejalin kerjasama antar sesama anggota.

Sikap kekeluargaan antar sesama anggota harus diutamakan agar terciptanya sebuah kesejahteraan. Setiap individu dari anggota tentu memiliki rasa tanggung jawab dan menyadari akan kewajiban dan haknya sehingga tujuan dari sebuah koperasi itu dapat terlaksana. Begitu banyak peranan pemikiran politik Hatta sehingga mempengaruhi perekonomian rakyat Indonesia.

\section{b. Saran}

Dengan beberapa temuan yang penulis lakukan dalam penelitian ini maka penulis dapat memberikan saran sebagai berikut :

1. Untuk penambahan ilmu, khususnya mengenai ilmu sejarah, dapat meningkatkan pemahaman tentang tokoh perjuangan bangsa Indonesia seperti Muhammad Hatta.

2. Untuk masyarakat, khususnya kota batam, dapat menumbuhkan rasa nasionalisme dalam diri, karena dapat mengetahui peran tokoh pejuang.

3. Penulis ingin mengajak pembaca, untuk mengikuti contoh karakter yang positif dari sosok Hatta.

4. Penulis ingin pembaca dapat mengambil pelajaran dari perjuangan sosok seorang Hatta dan menerapkannya dalam kehidupan sehari-hari. 


\section{DAFTAR PUSTAKA}

Afridal (2009). “ Triumvirat De Facto Tiga Pemimpin Soekarno-Hatta-Syahrir Dalam Perjuangan Kemerdekaan 1945-1947”. Skripsi, tidak diterbitkan, Universitas Riau Kepulauan, Batam

Anggaredho, P.P. (2008). " Pemikiran Ekonomi Mohammad Hatta di Tinjau dari Perspektif Ekonomi Islam”. Skripsi, tidak diterbitkan, Universitas Islam Negeri (UIN) Syarif Hidayatullah, Jakarta

Batubara. A.P. Demokrasi Buat Rakyat. Jakarta: Yayasan Proklamasi.

Daliman, (2012). Metode Penelitian Sejarah. Yogyakarta: Ombak

Effendi, Sulaiman. (2014). Kiprah \& Pemikiran Politik Tokoh-Tokoh Bangsa. Jogjakarta: IRCISOD

Feisal, Amir. J. (1995). “Reorientasi Pendidikan Islam” Jakarta: Gemainsani Press

Hendarsah, Amir. (2019). Buku Pintar Politik Sejarah, Pemerintahan, dan Kenegaraan. Yogyakarta: Jogja Great Publisher

Hidajat, Imam. (2001). “Teori-Teori Politik”. Malang: Setara Press

Isjwara, (1971), “Pengantar Ilmu Politik”. Bandung: Binacipta

Mujani, Saiful. (2007). “ Muslim Demokrat Islam, Budaya Demokrasi, dan Partisipasi Politik di Indonesia Pasca Orde Baru”. Jakarta: Gramedia Pustaka Utama

Maryati, Kun. (2001). “ Sosiologi”. Jakarta: Erlangga.

Pane, Nina. (2015). Politik Kebangsaan Ekonomi (1926-1977). Jakarta: Buku Kompas

Rosiyanti. (2011). "Perpecahan Dwitunggal Soekarno-Hatta Dan Pengaruhnya Terhadap Kebijakan Politik Indonesia Tahun 1956-1965”. Skripsi, tidak diterbitkan, Universitas Riau Kepulauan, Batam

Sujarweni, Wiratna. (2014). “Metodologi Penelitian”. Yogyakarta: Pustaka Baru Press

Suleman, Zulfikri. (2010). "Demokrasi Untuk Indonesia Pemikiran Politik Bung Hatta”. Jakarta: Buku Kompas 